\title{
亜鉛ーニッケル合金めっき浴からの共沈物の電解還元
}

\author{
林 秀考*, 五藤 佳子*, 田里伊佐雄*

\section{Electrochemical Reduction of the Precipitated Hydroxide Obtained from the Zn-Ni Alloy Plating Bath}

\author{
Hidetaka HAYASHI*, Yoshiko GOTO* and Isao TARI *
}

\begin{abstract}
With electrodeposition of $\mathrm{Zn}-\mathrm{Ni}$ alloy from a sulfate bath, less noble $\mathrm{Zn}$ preferentially deposits compared to noble Ni. This behavior is classified as "anomalous codeposition." The anomalous codeposition of $\mathrm{Zn}-\mathrm{Ni}$ may be due to the preferential precipitation of zinc hydroxide on the cathode and the inhibition of nickel deposition according to the hydrogen production at the cathode and the $\mathrm{pH}$ increase. However, when both $\mathrm{Zn}^{2+}$ and $\mathrm{Ni}^{2+}$ coexist in the solution, the zinc hydroxide does not precipitate while the double hydroxide of both metals does. In this paper, the role of the double hydroxide obtained from a plating bath containing $\mathrm{Zn}^{2+}$ and $\mathrm{Ni}^{2+}$ has been clarified. The double hydroxide production process and the electroreduction of the hydroxide have been investigated.
\end{abstract}

Key Words : Coprecipitates, Potentiometric Titration, Alloy Plating

\section{1. 緒言}

亜鉛一ニッケル合金は主として，鋼板に耐食性を付与 する皮膜として用いられている。この合金めっき皮膜を 電気めっき法で作る場合, 電気化学的に卑な金属である 业鉛が貴な金属であるニッケルに優先して析出すること

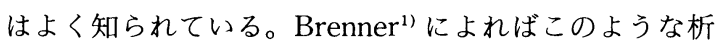
出挙動を示す合金めっきはいわゆる「異常型共析」に分 類されるが，その原因については未知の点も多い。

亜鉛一ニッケル合金めっきには，硫酸塩浴や塩化物浴 などの酸性浴が使用されている。水溶液では陰極表面で 金属の析出だけでなく水素発生も起こるため, 溶液本体 は酸性であっても陰極表面の $\mathrm{pH}$ は中性域まで上昇する ことが知られている22 4)。このことから, 陰極近傍に存 在する金属イオンは水酸化物を生成するなどの酸塩基反 応を起こし，この酸塩基反応が金属析出反応に影響を及 ほすことによりいわゆる「異常型共析」が起こるのでは ないかと考えられている(5) 8)。

Dahms らは5), ニッケルー鉄合金めつきに対する陰極

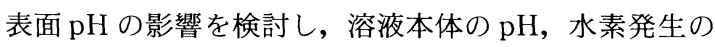
速度, 緩衝剤の濃度および拡散条件から陰極表面の $\mathrm{pH}$ を見積もる式を導出した。また，回転円板電極を用いた 測定結果から表面 $\mathrm{pH}$ が水酸化第一鉄の生成に十分な $\mathrm{pH}$ にまで上昇した場合にのみニッケルの析出が抑制さ れ，鉄がニッケルに優先して析出することを示した。

* 岡山大学 工学部 (₹700-8530 岡山県岡山市津島中 3-1-1) Fac. of Eng., Okayama Univ. (3-1-1, Tsushima-naka, Okayama-shi, Okayama 700-8530)
東らは6),7), 亜鉛一鉄族合金めっきにおいて, 電解電 流密度が転移電流密度と呼ばれる一定の值以上になると 陰極拡散層の $\mathrm{pH}$ が上昇し, 水酸化西鉛が生成し, これ が陰極に吸着して鉄族金属の析出が抑制され，亜鉛が優 先析出すると考えた。

以上の考え方はいずれも，優先析出する金属のイオン が陰極近傍で水酸化物を作り他の金属の析出を阻害する という観点からのものである。

しかしながら, めつき液中に 2 種類の金属イオンが共 存する場合, 必ずしもどちらか一方の金属イオンが優先 的に水酸化物を形成するとは限らない。滕らは9, $\mathrm{Zn}$ $\left(\mathrm{NO}_{3}\right)_{2}-\mathrm{Ni}\left(\mathrm{NO}_{3}\right)_{2}$ 混合系にアルカリを加えた際の水酸 化物生成を検討し, $\mathrm{Zn}^{2+}$ と $\mathrm{Ni}^{2+}$ が複合化しながら同時 に沈殿することを明らかにした。またこのような水酸化 物の複合化現象は, $\mathrm{Zn}^{2+}$ と $\mathrm{Ni}^{2+}$ にとどまらず多くの系 で見出されている。

本報告では，金属イオンを含む溶液にアルカリを滴下 することと, めっき時に水素発生のため陰極近傍の $\mathrm{pH}$ が上昇することには共通点があると考え, いわゆる「異 常型共析」において, 水酸化物の複合化が合金析出反応 に影響を与えている可能性があるとの観点から研究を進 めた。そこで, まずめつき浴にアルカリ溶液を加える際 の水酸化物の生成過程を電位差滴定法により検討し, X 線回折法などで生成物の分析同定を行った。次に, 得ら れた水酸化物を金属イオンを含まない溶液中で還元し, 析出した合金を走查型電子顕微鏡/エネルギー分散型 X 線分析装置で分析し，通常の合金めつきの挙動と比較し たので報告する。 
Table 1 Relation between the composition of $\mathrm{Zn} \cdot \mathrm{Ni}$ Alloys and applied potential.

\begin{tabular}{|c|c|c|c|c|c|c|c|c|}
\hline $\begin{array}{c}\text { Potential / } \\
\text { vs. Ag/AgCl }\end{array}$ & -0.7 & -0.9 & -1.0 & -1.1 & -1.2 & -1.3 & -1.4 & -1.5 \\
\hline $\mathrm{Ni} / \mathrm{wt} \%$ & 84 & 86 & 58 & 6 & 9 & 13 & 14 & 14 \\
\hline $\mathrm{Zn} / \mathrm{wt} \%$ & 16 & 14 & 42 & 94 & 91 & 87 & 86 & 86 \\
\hline $\begin{array}{c}\text { Current } \\
\text { efficiency/\% }\end{array}$ & trace & 0.3 & 0.3 & 40 & 43 & 33 & 24 & 55 \\
\hline
\end{tabular}

\section{2. 実験方法}

\section{1 溶液調製}

$\mathrm{ZnSO}_{4} \cdot 7 \mathrm{H}_{2} \mathrm{O}, \mathrm{NiSO}_{4} \cdot 6 \mathrm{H}_{2} \mathrm{O}$ (石津製薬侏製, 試薬特 級)を $\mathrm{pH}=2.0$ に調整した硫酸水溶液に溶かして, 0.1 $\mathrm{mol} \cdot \mathrm{dm}^{-3} \mathrm{ZnSO}_{4}, 0.1 \mathrm{~mol} \cdot \mathrm{dm}^{-3} \mathrm{NiSO}_{4}, 0.1 \mathrm{~mol} \cdot$ $\mathrm{dm}^{-3} \mathrm{ZnSO}_{4}+0.1 \mathrm{~mol} \cdot \mathrm{dm}^{-3} \mathrm{NiSO}_{4}$ の 3 種類の溶液を 調製した。

\section{2 電気めっき}

試験極として銅板(三津和化学薬品製, $99.9 \%$, 厚さ $0.5 \mathrm{~mm})$ を $2 \times 2 \mathrm{~cm}$ に切出したものを用い, $0.1 \mathrm{~mol}$ ・ $\mathrm{dm}^{-3} \mathrm{ZnSO}_{4}+0.1 \mathrm{~mol} \cdot \mathrm{dm}^{-3} \mathrm{NiSO}_{4}$ 中で定電位法によ り電解を行った。参照電極には $\mathrm{Ag} / \mathrm{AgCl}$ 電極を用い, めっき浴と参照電極を浸漬した飽和 $\mathrm{KCl}$ 溶液は, 寒天 橋 $\left(0.1 \mathrm{~mol} \cdot \mathrm{dm}^{-3} \mathrm{~K}_{2} \mathrm{SO}_{4}\right)$ で導通をとった。対極には亜 鉛板を用いた。電解前後の試験極の重量変化とクーロン メータで記録した通電量から電流効率を算出した。析出 合金中の $\mathrm{Zn} / \mathrm{Ni}$ の比率は走査型電子顕微鏡(侏)立製作 所製 S-3200 N)/エネルギー分散型 X 線分析装置(侏堀 場製作所製 EMAX-5770 W)によって決定した。

\section{3 電位差滴定}

自動滴定装置(東西電波工業(侏製，AUT-3000)を用い, マグネチックスターラーでかくはんしながら各溶液 100 $\mathrm{cm}^{3}$ に $1 \mathrm{~mol} \cdot \mathrm{dm}^{-3}$ の $\mathrm{KOH}$ を $0.2 \mathrm{~cm}^{3}$ ずつ 3 分間隔で 加えて電位差滴定を行った。

\section{4 生成した水酸化物の分析}

溶液 $100 \mathrm{~cm}^{3}$ に対して, 5.0, 10.0，17.5，25.0, $32.5 \mathrm{~cm}^{3}$ の $1 \mathrm{~mol} \cdot \mathrm{dm}^{-3}$ の $\mathrm{KOH}$ を加えて 4 分間かく はんし, 水酸化物の沈殿を生成させた。得られた水酸化 物を十分に水洗し, ろ過したのち乾燥器 $\left(60^{\circ} \mathrm{C}\right)$ で乾燥さ せた。これを乳鉢で粉砕した後, 粉末 X 線回折を行い (侏島津製作所製 XD-3 A を使用), 走查型電子顕微鏡 (侏)日立製作所製 S-3200 N)/エネルギー分散型 X 線分 析装置(侏)堀場製作所製 EMAX-5770 W)で分析し, 水 酸化物中の $\mathrm{Zn} / \mathrm{Ni}$ の比率を求めた。

\section{5 水酸化物の電解還元と析出物の分析}

沈殿反応により得た水酸化物 $100 \mathrm{mg}$ を錠剤成型器で $9.8 \times 10^{6} \mathrm{~Pa}$ で 1 分間加圧して成形した。得られたぺ レットを円形に切りだした銅板 $\left(1.5 \mathrm{~cm}^{2}\right)$ にせ，陰極 とした。なお，銅板は $15 \%$ リン酸溶液中で電解研磨し,
鏡面仕上げした。陽極には白金板を用いた。陰極，陽極 を $\mathrm{KOH} て ゙ \mathrm{pH}=9$ に調整した $0.1 \mathrm{~mol} \cdot \mathrm{dm}^{-3} \mathrm{~K}_{2} \mathrm{SO}_{4}$ 溶 液に浸漬し,これを密閉容器内に設置し窒素䨌囲気にし た後, $-1.4 \mathrm{~V}$ vs. $\mathrm{Ag} / \mathrm{AgCl}$ の設定電位で 24 時間電解 還元を行った。なお,この設定電位 $-1.4 \mathrm{~V}$ は, 別に測 定した定電位電流電位曲線から決定した。めっき後, 銅 板上のペレットを取り除き, 蒸留水で洗浄, 乾燥ののち, 走查型電子顕微鏡/エネルギー分散型 $\mathrm{X}$ 線分析装置で銅 板表面の観察と組成分析を行った。

\section{3. 結果および考察}

\section{1 電気めっき}

$\mathrm{pH}=2$ に調整した $0.1 \mathrm{~mol} \cdot \mathrm{dm}^{-3} \quad \mathrm{ZnSO}_{4}+0.1 \mathrm{~mol}$ ・ $\mathrm{dm}^{-3} \mathrm{NiSO}_{4}$ 溶液を用い定電位法により電解を行って得 た析出物の電流効率, $\mathrm{Zn} / \mathrm{Ni}$ 重量比と設定電位の関係 を表 1 に示した。なお, 電流効率の值は全般に通常の合 金めっきの場合よりも低いが，これは使用した浴の金属 イオン濃度が低いことや $\mathrm{pH}$ がやや低いことが原因と考 えられる。 $\mathrm{Ag} / \mathrm{AgCl}$ に対する電位がー $1.1 \mathrm{~V}$ 以下では 電流効率は $40 \%$ に達し, 亜鉛の析出量が多いことがわ かった。また， $-1.2 \mathrm{~V}$ 以下では亜鉛の含有率はやや低 くなり $80 \%$ 台となったが, 電位をさらに卑な值に設定 しても, 含有率はあまり変わらなかった。このように, 設定電位に関わらず析出した合金中の $\mathrm{Zn} / \mathrm{Ni}$ 比がほほ 一定となることから, 電極反応とは直接関係しない化学 反応によってめっき中間体が生成し，それが電極で還元 を受けて合金になる経路も考えられる。

この実験において電流効率は最大 $55 \%$ 程度であり, 副反応として水の分解による水素発生が起こっている。 したがって，陰極近傍では $\mathrm{pH}$ 上昇によってめっき金属 イオンから水酸化物が生成する条件が満たされている。 これらの結果を踏まえここではめっき反応の中間体とし て水酸化物が関与すると考えてさらに検討を進めた。

\section{2 水酸化物の生成過程}

図 1 はそれぞれ $100 \mathrm{~cm}^{3}$ の $0.1 \mathrm{~mol} \cdot \mathrm{dm}^{-3} \mathrm{ZnSO}_{4}$ (以 下 $\mathrm{ZnSO}_{4}$ 単独系と呼ぶ), $0.1 \mathrm{~mol} \cdot \mathrm{dm}^{-3} \mathrm{NiSO}_{4}$ (以下 $\mathrm{NiSO}_{4}$ 単独系と呼ぶ), $0.1 \mathrm{~mol} \cdot \mathrm{dm}^{-3} \mathrm{ZnSO}_{4}+0.1$ $\mathrm{mol} \cdot \mathrm{dm}^{-3} \mathrm{NiSO}_{4}$ (以下混合系と呼ぶ)に, $1 \mathrm{~mol} \cdot \mathrm{dm}^{-3}$ $\mathrm{KOH}$ を滴下した際の滴下量と $\mathrm{pH}$ の関係を示したもの である。 $\mathrm{ZnSO}_{4}$ 単独系の場合, $\mathrm{pH}=6.0$ から 6.5 にか 


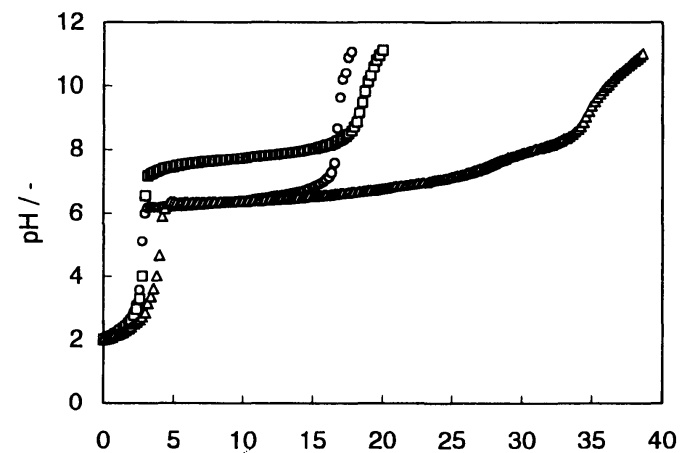

$1 \mathrm{~mol} \cdot \mathrm{dm}^{-3} \mathrm{KOH}$ added $/ \mathrm{cm}^{3}$

Fig. 1 Potentiometric titration curves.
$0: 0.1 \mathrm{~mol} \cdot \mathrm{dm}^{-3} \mathrm{ZnSO}_{4}$
$\square: 0.1 \mathrm{~mol} \cdot \mathrm{dm}^{-3} \mathrm{NiSO}_{4}$
$\triangle: 0.1 \mathrm{~mol} \cdot \mathrm{dm}^{-3} \mathrm{ZnSO}_{4}+0.1 \mathrm{~mol} \cdot \mathrm{dm}^{-3} \mathrm{NiSO}_{4}$

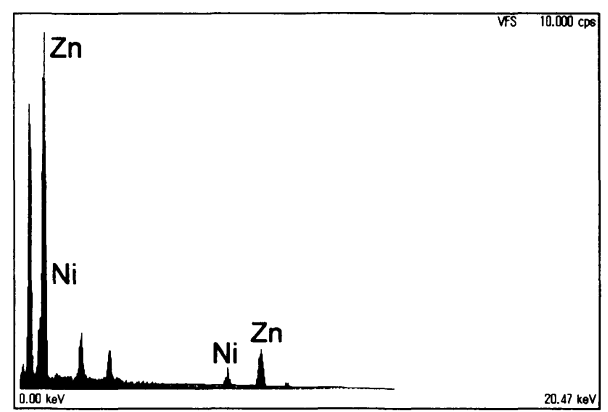

Fig. 2 EDX spectrum of the precipitate from $100 \mathrm{~cm}^{3}$ of $0.1 \mathrm{~mol} \cdot \mathrm{dm}^{-3} \mathrm{ZnSO}_{4}+0.1 \mathrm{~mol} \cdot \mathrm{dm}^{-3} \mathrm{NiSO}_{4}$ with 5 $\mathrm{cm}^{3}$ of $1 \mathrm{~mol} \cdot \mathrm{dm}^{-3} \mathrm{KOH}$.

けて水酸化亜鉛生成と思われる平坦部が出現した。また $\mathrm{NiSO}_{4}$ 単独系の場合, $\mathrm{pH}=7.5$ から 8.0 に水酸化二ッ ケル生成と思われる平坦部が出現した。 $0.1 \mathrm{~mol} \cdot \mathrm{dm}^{-3}$ $\mathrm{ZnSO}_{4}+0.1 \mathrm{~mol} \cdot \mathrm{dm}^{-3} \mathrm{NiSO}_{4}$ の場合, 滴下初期は水酸 化亜鉛生成の $\mathrm{pH}$ に近い值を示したが, $\mathrm{Zn}^{2+}$ からの水 酸化亜鉛の沈殿反応が完了すると思われる滴下量をこえ ても水酸化ニッケル生成の $\mathrm{pH}$ には至らず, $\mathrm{pH}$ はなだ らかに上昇していった。混合系において， $\mathrm{Zn}^{2+}$ からの 水酸化亜鉛生成ならびに $\mathrm{Ni}^{2+}$ からの水酸化ニッケルの 生成がそれぞれの水酸化物の溶解度積の順に逐次的に起 こるのであるならば，水酸化亜鉛の生成完了後に $\mathrm{pH}$ の 值は $1 \sim 1.5$ ジャンプし, 水酸化ニッケルの生成に対応 する新たな $\mathrm{pH}$ 平坦部が出現するはずである。実験結果 がそのようになっていないことは水酸化亜鉛でも水酸化 ニッケルでもない複合化した水酸化物の沈殿が生成して いることを示していると考えられる。

$100 \mathrm{~cm}^{3}$ の $0.1 \mathrm{~mol} \cdot \mathrm{dm}^{-3} \quad \mathrm{ZnSO}_{4}+0.1 \mathrm{~mol} \cdot \mathrm{dm}^{-3}$ $\mathrm{NiSO}_{4} に 1 \mathrm{~mol} \cdot \mathrm{dm}^{-3} \mathrm{KOH}$ を $5 \mathrm{~cm}^{3}$ 加えて得た水酸

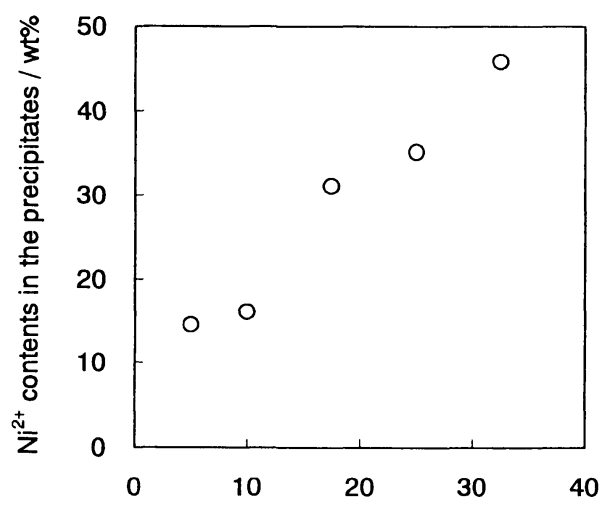

$1 \mathrm{~mol} \mathrm{dm}{ }^{-3} \mathrm{KOH}$ added $/ \mathrm{cm}^{3}$

Fig. 3 Relation between the amounts of added $\mathrm{KOH}$ solution and $\mathrm{Ni}^{2+}$ contents in the precipitates.

化物の EDX スペクトルを図 2 に示した。図 1 の滴定曲 線から判断すると，この試料の作製条件では $\mathrm{Zn}^{2+}$ が優 先して沈殿すると考えられる。しかし EDX スペクトル には，Znだけでなく Ni のピークも観測されている。 すなわち, 水酸化物生成の初期段階から $\mathrm{Ni}^{2+}$ が $\mathrm{Zn}^{2+}$ とともに沈殿物に含まれていることが分かる。

図 1 を参考にして $100 \mathrm{~cm}^{3}$ の $0.1 \mathrm{~mol} \cdot \mathrm{dm}^{-3} \mathrm{ZnSO}_{4}+$ $0.1 \mathrm{~mol} \cdot \mathrm{dm}^{-3} \mathrm{NiSO}_{4}$ に $1 \mathrm{~mol} \cdot \mathrm{dm}^{-3} \mathrm{KOH}$ をそれぞれ， $5.0,10.0,17.5,25.0,32.5 \mathrm{~cm}^{3}$ 加えて水酸化物を生 成させ(これらをそれぞれサンプル A, B , C , D , E と表 す), 得られた水酸化物中の $\mathrm{Zn} / \mathrm{Ni}$ 比を $\mathrm{EDX}$ により求 めたところ図 3 に示す結果を得た。水酸化物生成の初期 段階から $\mathrm{Ni}^{2+}$ が $\mathrm{Zn}^{2+}$ 亜鉛とともに含まれていること が示されている。

図 4 にサンプル A〜E の粉末 $\mathrm{X}$ 線回折図形を示す。 比較のため $0.1 \mathrm{~mol} \cdot \mathrm{dm}^{-3} \mathrm{ZnSO}_{4}$ 単独系に $1 \mathrm{~mol} \cdot \mathrm{dm}^{-3}$ $\mathrm{KOH}$ を $15.0 \mathrm{~cm}^{3}$ 加えて生成させた水酸化物の沈殿の $\mathrm{X}$ 線回折図形も示した。 $\mathrm{A} \sim \mathrm{C}$ の回折図形のピークは, $2 \theta=20^{\circ}$ 付近のピークを除き基本的には同じ位置に出現 している。また沈殿生成のために加えるアルカリの量が $\mathrm{A}, \mathrm{B}, \mathrm{C}$ と增えるに従い回折ピークは, より明瞭に なっている。さらに, C の回折図形は $2 \theta=20^{\circ}$ 付近の ピークを含めて $\mathrm{ZnSO}_{4}$ 単独系からの沈殿物 (以下，水酸 化亜鉛とあらわす)の回折図形と類似である。既に述べ たように，滴定の初期に相当するアルカリ添加量が少な い段階での沈殿物の中に $\mathrm{Ni}^{2+}$ が含まれていることと併 せて考えると, 滴定の前半部分では $\mathrm{Ni}^{2+}$ と $\mathrm{Zn}^{2+}$ を含 む水酸化亜鉛に類似した構造の化合物が生成していると 考えられる。

アルカリ添加量 $25 \mathrm{~cm}^{3}$ 以上で生成した $\mathrm{D}, \mathrm{E} て ゙ は \mathrm{~A}$ 〜Cで見られた水酸化亜鉛のピークはほとんどみられな 


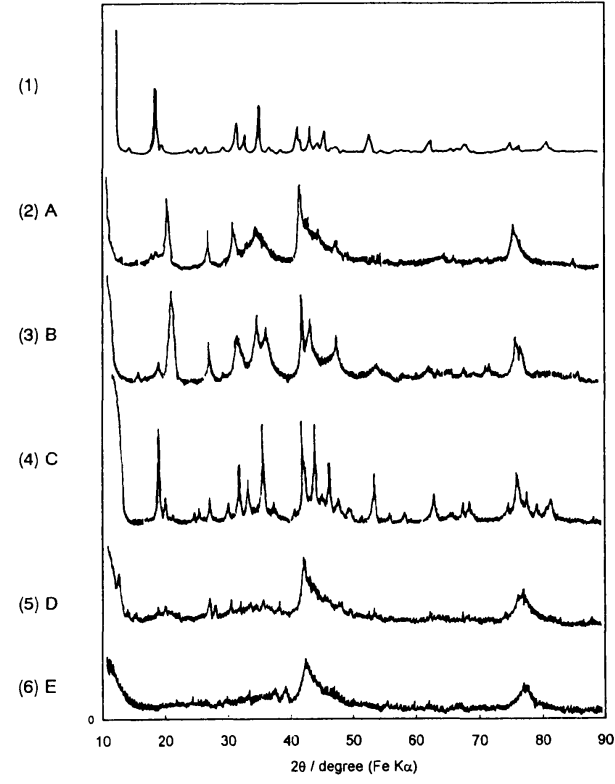

Fig. 4 XRD patterns of the precipitates obtained from,

(1) $100 \mathrm{~cm}^{3}$ of $0.1 \mathrm{~mol} \cdot \mathrm{dm}^{-3} \mathrm{ZnSO}_{4}$ with $15 \mathrm{~cm}^{3}$ of $1 \mathrm{~mol} \cdot \mathrm{dm}^{-3} \mathrm{KOH}$

(2) $\mathrm{A} ; 100 \mathrm{~cm}^{3}$ of $0.1 \mathrm{~mol} \cdot \mathrm{dm}^{-3} \mathrm{ZnSO}_{4}+0.1 \mathrm{~mol} \cdot$ $\mathrm{dm}^{-3} \mathrm{NiSO}_{4}$ with $5 \mathrm{~cm}^{3}$ of $1 \mathrm{~mol} \cdot \mathrm{dm}^{-3} \mathrm{KOH}$

(3) $\mathrm{B} ; 100 \mathrm{~cm}^{3}$ of $0.1 \mathrm{~mol} \cdot \mathrm{dm}^{-3} \mathrm{ZnSO}_{4}+0.1 \mathrm{~mol} \cdot$ $\mathrm{dm}^{-3} \mathrm{NiSO}_{4}$ with $10 \mathrm{~cm}^{3}$ of $1 \mathrm{~mol} \cdot \mathrm{dm}^{-3} \mathrm{KOH}$

(4) $\mathrm{C} ; 100 \mathrm{~cm}^{3}$ of $0.1 \mathrm{~mol} \cdot \mathrm{dm}^{-3} Z_{n^{2}}+0.1 \mathrm{~mol} \cdot$ $\mathrm{dm}^{-3} \mathrm{NiSO}_{4}$ with $17.5 \mathrm{~cm}^{3}$ of $1 \mathrm{~mol} \cdot \mathrm{dm}^{-3} \mathrm{KOH}$

(5) $\mathrm{D} ; 100 \mathrm{~cm}^{3}$ of $0.1 \mathrm{~mol} \cdot \mathrm{dm}^{-3} Z_{\mathrm{nSO}_{4}}+0.1 \mathrm{~mol} \cdot$ $\mathrm{dm}^{-3} \mathrm{NiSO}_{4}$ with $25 \mathrm{~cm}^{3}$ of $1 \mathrm{~mol} \cdot \mathrm{dm}^{-3} \mathrm{KOH}$

(6) $\mathrm{E} ; 100 \mathrm{~cm}^{3}$ of $0.1 \mathrm{~mol} \cdot \mathrm{dm}^{-3} \mathrm{ZnSO}_{4}+0.1 \mathrm{~mol} \cdot$ $\mathrm{dm}^{-3} \mathrm{NiSO}_{4}$ with $32.5 \mathrm{~cm}^{3}$ of $1 \mathrm{~mol} \cdot \mathrm{dm}^{-3} \mathrm{KOH}$

い。 D, E の回折図形は $\mathrm{NiSO}_{4}$ 単独系からの沈殿物の回 折図形とも異なっていた。滴定の後半部分で, 溶液中に 残存している $\mathrm{Ni}^{2+}$ から水酸化ニッケルが生成するので あれば，水酸化西鉛のピーク以外に水酸化ニッケルに相 当するピークが観察されるはずであるが結果はそうなっ ていない。したがって，A〜C とは異なる複合化した水 酸化物が生成していると考えられるが，その詳細は今後 検討する必要がある。

以上のことから，亜鉛ーニッケル合金めっきでは陰極 表面の $\mathrm{pH}$ 上昇にともない，水酸化亜鉛だけではなく $\mathrm{Zn}^{2+}$ と $\mathrm{Ni}^{2+}$ の複合化した水酸化物が形成されており, その形態や組成は水酸化物生成時の $\mathrm{pH}$ に依存すると考 えられる。

\section{3 沈殿物の電解還元と生成物の分析}

前節での検討より $\mathrm{Zn}^{2+}$ と $\mathrm{Ni}^{2+}$ が共存している溶液 の $\mathrm{pH}$ が上昇すると複合化した水酸化物が生成すること が明らかとなった。また $\mathrm{pH}$ 上昇の初期段階では複合化

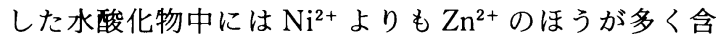

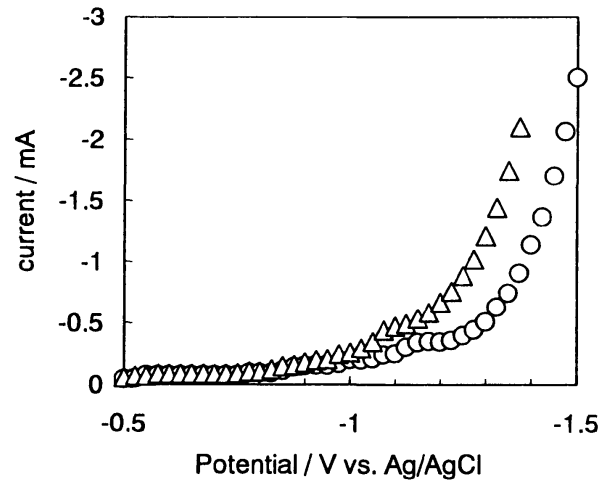

Fig. 5 Potentiostatic i-E curves for electroreduction of the precipitates in $0.1 \mathrm{~mol} \cdot \mathrm{dm}^{-3} \mathrm{~K}_{2} \mathrm{SO}_{4}$ solution.

$\bigcirc: \mathrm{Zn}(\mathrm{OH})_{2}$

$\triangle$ : sample $B$

まれることが明らかとなった。既に述べたようにめっき 時には陰極近傍の $\mathrm{pH}$ は上昇することから，このような 複水酸化物がめっき時に生成することは十分考えられる。 ここではこの複水酸化物の電解還元を試み合金が得られ るかどうか検討した。

図 5 に，試料 B および水酸化亜鉛をそれぞれ錠剤成 型したものを 2.5 節で示した方法で銅板上に保持し 0.1 $\mathrm{mol} \cdot \mathrm{dm}^{-3} \mathrm{~K}_{2} \mathrm{SO}_{4}$ 溶液中で電解還元した際の電流電位 曲線を示した。なお測定は定電位法で行い, 電位設定後 5 分経過後の電流值をサンプリングして電流電位曲線を 得た。 $-0.8 \mathrm{~V}$ より卑な領域で電流の増加が見られるが これは水素発生によるものと考えられる。水酸化亜鉛の 場合に $-1.15 \mathrm{~V}$ 付近に, 試料 $\mathrm{B}$ の場合には, $-1.07 \mathrm{~V}$ に電流の平坦部が見られるが，これがそれぞれの水酸化 物の還元に対応すると考えられる。

そこで電位を $-1.4 \mathrm{~V}$ に設定して 24 時間電解還元を 行った後, 電極表面の付着物を取り除き, 蒸留水で洗 浄・乾燥ののち, SEM/EDX で表面の観察を行った。 比較のため, 水酸化亜鉛と水酸化ニッケルについても実 験を行った。その結果, 水酸化亜鉛は電解還元すること ができ，銀白色の亜鉛と思われる析出物が得られたが， 水酸化ニッケルを還元することはできなかった。 $\mathrm{A} \sim \mathrm{E}$ の試料はいずれも還元することができた。図 6 は, 試料 $\mathrm{B}$ の SEM/EDX 像を示す。EDX スペクトルにおいて $0.5 \mathrm{KeV}$ 付近に酸素 $\mathrm{K} \alpha$ のピークがほとんど見られな いことから銅板上に水酸化物でなく合金が析出している と考えられる。表 2 には, 各試料を電解還元した後銅板 上に得られた合金中の $\mathrm{Zn} / \mathrm{Ni}$ 比を示した。サンプル $\mathrm{A}$ の場合には亜鉛の比率がやや高いが，これは滴定の初期 の生成物にはもともと $\mathrm{Ni}^{2+}$ があまり含まれていないこ とによる。B以降のサンプルについては，ほほ同一の合 金組成であった。図 4 に示したように，A〜Cのサンプ 


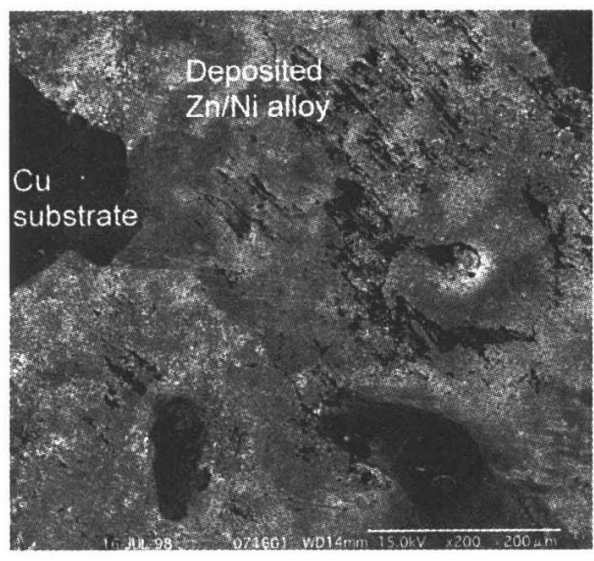

SEM

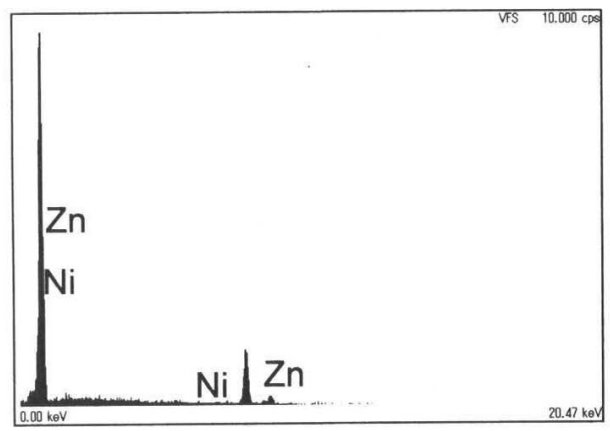

EDX spectrum

Fig. 6 Scanning electron micrograph and EDX spectrum of the reduction product of the hydroxide precipitates.

Sample B, x $200 \quad \mathrm{Zn} / \mathrm{Ni}=87 / 13$

ルと $\mathrm{D}, \mathrm{E}$ とは異なる水酸化物と考えられる。既に述べ たように水酸化亜鉛はこの条件で還元可能であるので, $\mathrm{Zn}^{2+}$ の含有率が高く水酸化亜鉛に類似した $\mathrm{A} \sim \mathrm{C}$ のサ ンプルは還元されて亜鉛の比率が高い合金になったもの と考えられる。D，Eについては，その一部が還元され にくい水酸化ニッケルになっており，残りの $\mathrm{Zn}^{2+}$ を多 く含む部分が還元されたとも考えられるが，XRDの結 果からは判断できない。

実験の結果，亜鉛とニッケルの複合化した水酸化物を 還元して得られた合金の組成は, 表 1 に示した合金めっ
Table $2 \mathrm{Zn} / \mathrm{Ni}$ weight ratio of the reduction products of the precipitates.

\begin{tabular}{|c|c|}
\hline Precipitate & $\mathrm{Zn}: \mathrm{Ni}$ \\
\hline Sample A & $95: 5$ \\
\hline Sample B & $87: 13$ \\
\hline Sample C & $88: 12$ \\
\hline Sample D & $87: 13$ \\
\hline Sample E & $84: 16$ \\
\hline
\end{tabular}

き浴からの析出合金の組成に近いことがわかったが，B 〜 E の試料の還元時の合金組成がほほ同じ理由について は, 水酸化物の構造などについて今後検討が必要と考え ている。

\section{4. 結 論}

亜鉛一ニッケル合金めっき時には水素発生のため陰極 表面の $\mathrm{pH}$ が上昇するが，このとき生成するのは水酸化 亜鉛ではなく，亜鉛とニッケルが複合化した水酸化物で ある。この水酸化物を合成し電解還元すると，合金めっ きで得られるものと類似組成をしめすニッケルに比べて 亜鉛の割合が多い合金が得られた。

このことから，亜鉛ーニッケル合金めっきにおいて， 亜鉛とニッケルが複合化した水酸化物を経由する反応経 路が存在する可能性が示された。

(Received September 24, 1999 : Accepted March 13, 2000)

\section{文献}

1) A. Brenner, Electrodeposition of Alloys, Academic Press, New York and London, (1963)

2 ) 西村一実, 三吉康彦, 羽田隆司：金属表面技術, 38, 217 (1987)

3 ）津留 豊, 山部賢二, 細川邦典：表面技術, 40, 345 (1989)

4 ) 東敬, 福島久哲, 秋山哲也, 日野英治：西日本防蝕研究, 8 , 1 (1977)

5 ) H. Dahms, I. M. Croll ; J. Electrochem. Soc., 112, 771 (1965)

6 ) 東 敬；表面技術, 42, 1134，(1991)

7 ) H. Fukushima, T. Akiyama, J. H. Lee, M. Yamaguti, K. Higashi : Trans. J. I. M., 24, 125 (1983)

8 ) 安谷屋武志；東京大学学位論文，(1987）

9 ) 滕 永紅, 武田真一, 田里伊佐雄；日本化学会誌, 1995, 426, (1995) 